Editorial

\title{
Zika Virus- A Global Health Emergency
}

\author{
Rabindran ${ }^{1}$, Gedam DS ${ }^{2}$ \\ ${ }^{1}$ Dr. Rabindran, Consultant Neonatologist, Billroth Hospital, Chennai, ${ }^{2}$ Dr D Sharad Gedam, Professor of Pediatrics, \\ L.N. Medical College, Bhopal, MP, India.
}

Address for correspondence: Dr Rabindran, E mail: rabindranindia@ yahoo.co.in

\begin{abstract}
Zika Virus is emerging as global emergency. We are presenting here a brief epidemiological profile, brief clinical features and preventive aspects of Zika virus fever globally.
\end{abstract}

Keywords: Zikavirus, Microcephaly, Arbovirus

\section{Introduction}

Zika fever is caused by Zikavirus, an arbovirus belonging to family Flaviviridae, genus Flavivirus. Zikavirus is enveloped, icosahedral \& has a nonsegmented, single-stranded, positive-sense RNA genome. It is transmitted by daytime active Aedes mosquitoes likeA.aegypti \& A.albopictus. It was first isolated in Zika forest of Uganda in 1947 from a rhesus monkey [1]. Human spread occurred in1952 at Uganda \& Tanzania. Major outbreaks started in 2007 from Micronesia [2] due to combination of factors like climatic change, urbanization \& easy access to travel. Nearly 4 million people are estimated to be infected by the end of this year.

WHO has recently declared Zikavirus as a global health emergency linked to thousands of birth defects like microcephaly, intracranial calcifications, ventriculomegaly, neuronal migration disorders (lissencephaly, pachygyria), congenital contractures \& clubfoot.

During an outbreak in 2015 at Brazil, nearly 4000 cases of microcephaly was reported- a 20 fold increase from previous years. The virus has been isolated in amniotic fluid of pregnant women carrying babies with birth defects \& also in brain of babies with microcephaly. However apart from pregnant women in general population only one of five people infected with virus develops symptoms. The symptoms are similar to arbovirus infections like dengue \& include fever, skin rashes, conjunctivitis, muscle \& joint pain, malaise \& headache. The incubation period in the body after mosquito bite varies between 2-12 days\& symptoms start between $3^{\text {rd }} \& 7^{\text {th }}$ day. Most of them recover within 7 days\& may not even need hospitalisation. However neurologic complications like Guillain-Barre syndrome have been reported [3].

Zika fever is usually transmitted by Aedes mosquitoes. However transmission by perinatal route transfusion \& sexual intercourse [7] have been reported [4,5,6]. CDC has advised men who have lived or travelled to endemic areas to use condoms or abstain from sex to avoid zika virus spread. The virus remains in blood for about a week $\&$ in semen for up to 2 weeks. Diagnosis can be established by serum reverse transcriptase-polymerase chain reaction (RT-PCR), virus-specific IgM \& neutralizing antibodies; Plaque-reduction neutralization testing (PRNT). For pregnant women, negative IgM test result 2-12 weeks after exposure excludes Zika virus infection. There is no specific medication available for Zika Fever. Treatment includes bed rest, hydration, analgesics \& antipyretics. Preventive measures include protection against mosquito bites by source reduction using insect repellents containing >20\% DEET, mosquito nets, physical barriers such as screens, permethrin-treated clothing\& spraying of insecticides.

Recently an Indian company has been working on vaccines for the Zika virus based on two approaches: "recombinant", involving genetic engineering \& "inactivated", where the virus is incapable of reproducing itself but can still trigger an immune response. However it may take some time for regular use of these vaccines. Moreover the full spectrum of outcomes associated with infection during pregnancy \& 
the factors that might increase risk to the fetus are not yet fully understood. More research is required to learn about the risks of Zika virus infection during pregnancy and its prevention.

\section{Funding: Nil, Conflict of interest: Nil \\ Permission from IRB: Yes}

\section{Reference}

1. DICK GW, KITCHEN SF, HADDOW AJ. Zika virus. I. Isolations and serological specificity. Trans $\mathrm{R}$ Soc Trop Med Hyg. 1952 Sep;46(5):509-20.

2. Duffy MR, Chen TH, Hancock WT, Powers AM, Kool JL, Lanciotti RS, Pretrick M, Marfel M, Holzbauer S, Dubray C, Guillaumot L, Griggs A, Bel M, Lambert AJ, Laven J, Kosoy O, Panella A, Biggerstaff BJ, Fischer M, Hayes EB. Zika virus outbreak on Yap Island, Federated States of Micronesia. N Engl J Med. 2009 Jun 11;360(24):2536-43. doi: 10.1056/NEJMoa0805715.

3. Fauci AS, Morens DM. Zika Virus in the Americas Yet Another Arbovirus Threat. N Engl J Med. 2016 Jan 13. [Epub ahead of print].

\section{Editorial}

4. Hayes EB. Zika virus outside Africa. Emerg Infect Dis. 2009 Sep;15(9):1347-50. doi: 10.3201/ eid1509. 090442.

5. Besnard M, Lastère S, Teissier A, Cao-Lormeau VM, Musso D. Evidence of perinatal transmission of Zika virus, French Polynesia, December 2013 and February 2014 . Euro Surveill. 2014;19(13):pii=20751. Article DOI: http :// dx.doi.org/10.2807/1560-7917. ES2014. 19.13.20751

6. Musso D, Nhan T, Robin E, Roche C, Bierlaire D, Zizou K, et al. Potential for Zika virus transmission through blood transfusion demonstrated during an outbreak in French Polynesia, November 2013 to February 2014. Euro Surveill. 2014 Apr 10;19(14). pii: 20761.

7. Foy BD, Kobylinski KC, Chilson Foy JL, Blitvich BJ, Travassos da Rosa A, Haddow AD, Lanciotti RS, Tesh RB. Probable non-vector-borne transmission of Zika virus, Colorado, USA. Emerg Infect Dis. 2011 May;17(5):880-2. doi: 10.3201/eid1705.101939.

\section{How to cite this article?}

Rabindran, Gedam DS. Zika Virus- A Global Health Emergency. Trop J Path Micro 2016; 2(1):1-2.doi: 10.17511/jopm.2016.101.01 